Reprod. Nutr. Dévelop., 1981, 21 (6B), 1059-1065.

\title{
A comparison of the reproductive and growth performances of offspring from broiler breeder males selected for early growth rate using artificial insemination and unselected males kept on deep litter
}

\author{
by F. VAN WAMBEKE, R. MOERMANS *, G. DE GROOTE \\ Rijksstation voor Kleinveefeelt, Burg. Van Gansberghelaan, 92, 9220 Merelbeke \\ * Bureau voor Biometrie, Burg. Van Gansberghelaan, 96, 9220 Merelbeke, Belgium.
}

Summary. Broiler breeder males were selected for early growth rate at 5 weeks of age (average weight +0.5 SD). The reproductive and growth performances of the offspring of these males using artificial insemination with stored semen was compared with those from non-selected males kept on deep litter under conditions of natural mating.

On three different occasions ( 31,41 and 51 weeks of age), the eggs of the two treatments were incubated and, although the reproductive performances showed little difference over the entire period, hatchability of eggs set was significantly $(p<0.01)$ higher for the field hens on the first occasion. The opposite was true after 50 weeks of age due to a serious decline in fertility in natural mating.

At all periods, the selected males produced significantly $(p<0.01)$ heavier offspring at six weeks of age.

\section{Introduction.}

In a recent experiment (Van Wambeke ef al., 1979) broiler breeder males were selected for study on the basis of their 3-week body weight and divided into heavy (average weight $+0.5 \mathrm{SD}$ ) and « all » males. There was no difference in semen qualify and reproductive performance between the two groups. The heavy males produced slight but not significantly heavier offspring at 6 weeks of age. The correlation between early and 20-week body weight was low, and also it was advisable to select the males at the slaughter age of their offspring. Feed restriction usually starts at 3 weeks of age which is probably too early for selection. In the present experiment the birds were moderately restricted from 3 to 5 weeks and selection was based on the 5-week body weight. Since heavy males of the population showed normal reproductive performances it is interesting to compare the body weight of their offspring with that of males which were not selected for early growth rate and kept on deep litter.

\section{Material and methods.}

Rearing and selection of males. - One hundred and fifty-six 1-d-old broiler breeder males (Hubbard, White Mountain) were placed on deep litter in a windowless house 
on 14th November 1978. They were fed a starter diet ad libitum containing 11.7 MJ $\mathrm{ME} / \mathrm{kg}$ and $18 \mathrm{p} .100$ crude protein to 3 weeks of age. From 3 to 5 weeks the same diet was supplied following a moderate restriction : daily intake of $75 \mathrm{~g}$ from 3-4 weeks and $80 \mathrm{~g}$ from 4-5 weeks. From 5 to 8 weeks of age, the birds on a skip-a-day program were given $180 \mathrm{~g}$ on the first of two successive days. At 8 weeks of age, the males received a growing ration containing $11.7 \mathrm{MJ} \mathrm{ME} / \mathrm{kg}$ and $14 \mathrm{p} .100$ crude protein. This diet was given as follows : $8-15$ weeks : $180 \mathrm{~g}$ of mash the first day and $10 \mathrm{~g}$ of oats per bird the 2nd day ; $15-19$ weeks : $200+10 ; 19-20$ weeks : $220+10$.

At 20 weeks of age the males were again switched to a daily allowance of a breeder diet containing 11.13 MJ ME $/ \mathrm{kg}$ and $16.5 \mathrm{p} .100$ crude protein. The allowance was increased from 120 to $150 \mathrm{~g} / \mathrm{male}$ and was kept at that level during the reproductive period. The birds were reared under a controlled lighting program with $8 \mathrm{~h} / \mathrm{d}$ until 18 weeks. From 18 weeks they received $10 \mathrm{~h}$, at 19 weeks 11 and at 20 weeks, when they were transferred to the windowed cage house, they were kept at $16.30 \mathrm{~h}$ per day. This photoperiod was maintained throughout the experimental period.

At 5 weeks 147 birds were weighed individually and 51 birds had a body weight higher than the average plus one-half of the standard deviation.

At 20 weeks, the 132 birds still alive were weighed again. Of the 51 heavy males, 44 remained at 20 weeks of age and they were trained for semen collection according to Van Wambeke's second method (1976). Twenty-eight males survived a macroscopic semen selection and their semen was further evaluated individually by preparing smears of undiluted semen between 24-28 weeks of age (Van Der Schaaf, 1952). The following types of spermatozoa were distinguished : normal uncoloured, dead spermatozoa which had taken up the stain to some degree (included coloured bent mid-pieces) and other abnormals (including uncoloured bent mid-pieces). After staining, the average percentage of normal uncoloured spermatozoa from the 28 males was 91.5 (SD : 3.81). The concentration of pooled semen was determined at $5(n: 5)$ different intervals of the reproductive period using an autocytometer, and an average value of 8.07 (SD : 0.09$) \times 10^{9} / \mathrm{ml}$ was obtained. Males which went out of semen production during the experiment were removed. Semen volume declined with age and males producing less than $0.4 \mathrm{ml}$ of normal semen per ejaculate were removed. At 41 weeks semen was collecled from 21 males and at 51 weeks from 18 males. However, the percentage of normal spermatozoa (as calculated from the 24-28 period) was still 90.

Mode of reproduction. - Ten groups of 18 hens each of the same strain and age as the males were selected at peak lay on the basis of normal, hatchable egg production. They received approximately $160 \mathrm{~g} /$ hen/day from a dief containing $10.88 \mathrm{MJ} \mathrm{ME} / \mathrm{kg}$, 16.5 p. 100 crude protein, 2.7 p. $100 \mathrm{Ca}$ and 0.4 p. 100 available $P$. The hens were housed in individual cages and inseminated with $0.1 \mathrm{ml}$ of diluted (three-fold) semen that was stored for $3 \mathrm{~h}$ in a reconstituted freeze-dried diluent (Van Wambeke, 1972) at $2{ }^{\circ} \mathrm{C}$. The number of spermatozoa inseminated was approximately $260 \times 10^{6}$. Hatching eggs from hens of the same strain were obtained from a commercial breeder. The hens (3500) were housed on deep litter with $1 / 3$ of the surface as slat floor. At housing, the males (10 p. 100) were macroscopically selected on the basis of visual reproductive capacities and health, not on body weight. The males and females on deep litter were fed a diet of $11.92 \mathrm{MJ} \mathrm{ME} / \mathrm{kg}, 16$ p. 100 crude protein, $2.5 \mathrm{p} .100 \mathrm{Ca}$ and 0.49 p. 100 avai- 
lable $P$. The ration was provided in a controlled way according to the laying performances. Eggs from caged hens are heavier than those from floor hens, thus to compensate for the difference in egg weight the hens chosen in the field were three weeks older than their caged counterparts. Furthermore the hens in cages received less calories of ME per day.

At the age of 31,41 and 51 weeks the 10 groups of caged hens were inseminated mid-vaginally and their eggs were collected for 7 or 8 days. A number of 25 reserve hens were also inseminated. Three days after insemination 1000 (1 100 at 51 weeks) eggs from the production of one day of the field hens were collected, transported and stored at $\pm 15^{\circ} \mathrm{C}$ together with the eggs from the inseminated hens. The production of hatching eggs under conditions of natural mating is a continuous process; to simulate this with artificial insemination all caged hens were inseminated on two successive weeks at 30, 31 and 50,51 weeks of age. At 41 weeks hens were only inseminated once ; they were previously used for work concerning duration of fertility. Since some earlymorning eggs from the second day after insemination could be infertile, the fertility results from insemination at 41 weeks were based on the eggs laid between the 3rd and the 9th day after insemination. Experiments (Van Wambeke, 1980) have shown that there is very little or no difference in fertility and hatchability between eggs collected from the 2 nd to the 8 th day and those collected from the 2 nd through the 10 th day after insemination, provided that insemination is not performed after 50 weeks of age.

Hatching egg characteristics. - At each period, the eggs from the field were divided at random into 10 groups of 90 eggs each and weighed; using a Schoorl and Boersma apparatus (Schoorl and Boersma, 1962), shell deformation was measured on a sample of 30 eggs at 41 and 51 weeks. The eggs from the ten groups of inseminated hens were also weighed and shell deformation measured. Settable eggs from the ten groups of inseminated hens were incubated together with the eggs from reserve hens. The ten groups of eggs from the field hens together with the rest were incubated at the same time.

Determination of fertility and hatchability. - Fertility and hatchability results were based on the number of eggs laid during the 2 nd and the 8 th day after insemination for the 31 and 51-weeks periods. Fertility was determinated 19 days after incubation and clear and questionable eggs were broken open and investigated macroscopically for fertility. Hatchability was recorded as the number of chicks which hatched 22 days after incubation. After the hatchability data of the different replicates were recorded, the chicks from each treatment, including the reserves, were intermingled and sexed.

Tests of offspring. - In the first progeny test, 15 replicates of 25 male and 25 female chicks from each treatment $(15 \times 2 \times 2=60$ pens $)$ were placed in the brooder house. In the second test, the number of chicks was 26 per replicate. In the last test the number of chicks was again 25 per replicate but the number of female replicates originating from Al was only 14.

In all progeny tests the chicks were placed on a broiler ration containing $13.38 \mathrm{MJ}$ $\mathrm{ME} / \mathrm{kg}$ and 22.5 p. 100 crude protein. Body weight and feed consumption were determined at 6 weeks of age.

Statistical analysis. - Fertility and hatchability percentages were transformed to 
$\arcsin \sqrt{\%}$ and analysed according to Student's t-test (Snedecor and Cochran, 1967). Egg weight, shell deformation, 6-week body weight and food consumption were also subjected to a t-test while mortality was analysed by Chi-Square.

\section{Results and discussion.}

Results. - The correlation coefficient between the body weight of the males at 5 weeks and that at 20 weeks of age was $0.423(p<0.01, n=132)$. The average body weight of the 147 birds at 5 weeks was $998 \mathrm{~g}(S D=106 \mathrm{~g})$. The average body weight of the 51 birds which were classified as heavy was $1097 \mathrm{~g}$ (lowest limit : $1050 \mathrm{~g}$ ). The average 5 and 20-week body weights of the 44 males at 20 weeks were 1099 and $2961 \mathrm{~g}$, respectively, while the average weights of the 28 selected males were 1091 and $2975 \mathrm{~g}$, respectively. Egg weights (table 1) were very comparable during the two

TABLE 1

Egg weight and shell deformation of eggs originating from inseminated cage hens and naturally mated floor hens

\begin{tabular}{lccccccc}
\hline & \multicolumn{9}{c}{ Periods } \\
\cline { 2 - 7 } & \multicolumn{2}{c}{31 weeks } & \multicolumn{2}{c}{41 weeks } & \multicolumn{2}{c}{51 weeks } \\
\cline { 2 - 8 } & Al & NM & Al & NM & Al & NM \\
\hline Egg weight $(g) \ldots \ldots \ldots \ldots \ldots$ & 59.6 & 59.9 & 65.6 & 65.2 & 69.5 & 68.3 \\
Shell deformation $(0.001 \mathrm{~mm}) .$. & - & - & 22.9 & 23.4 & 23.6 & $21.3^{* *}$ \\
\hline
\end{tabular}

** Significant difference $(\mathrm{P}<0.01)$.

first periods, while the third period showed a difference of about one gram in favour of the eggs from caged hens. It may, therefore, be concluded in the present experiment that the possible effect of egg weight on the body weight of the offspring was neutralised. Eg ghell quality is an important factor for good hatchability (Mc Daniel ef al., 1979). There was no difference in shell deformation at 41 weeks but the shells of eggs from Al hens were significantly weaker at 51 weeks. Since hatchability of fertile eggs was only slightly better for eggs originating from naturally mated (NM) hens, this factor is not believed to be important for this parameter. Fertility and hatchability results during the three periods are shown in table 2 . Fertility was high for both treatments when the breeders were 31 and 34 weeks of age. At this period, however, hatchability of fertile eggs was significantly $(P<0.05)$ higher for the NM hens and this is directly reflected in hatchability of total eggs set.

Reproductive results in the second period were equal for both treatments. In the Al treatment, eggs were collected from the 3 rd through the 9 th day after insemination. Hatchability of eggs set in the NM treatment was lower than the target value given by the breeder ( 86.9 vs 89 p. 100). After 51 weeks of age fertility in the NM hens dropped seriously, the difference in fertility and hatchability of eggs set was.highly significant $(p<0.01)$ between the two treatments. Performances of the offspring from both selected males used for Al and nonselected males on deep litter are also given in 
TABLE 2

Reproductive and growth performances of the offspring of broiler breeder males selected for early growth using Al compared with unselected males kept on deep litter

Periods

\begin{tabular}{l}
\cline { 2 - 7 } \\
\cline { 2 - 8 }
\end{tabular}

table 2. At the three periods there was a significant $(p<0.01)$ higher body weight at six weeks of age for both and female offspring from the selected males. In the first progeny test, mortality in both males and females resulting from Al was significantly higher $(\delta: p<0.01 ; q: p<0.05)$ than in chicks hatched from floor eggs. Mortality, starting on the 10th day, was diagnosed as fatty liver and kidney syndrome. The cause was not clear, a 5 p. 100 vitamin and mineral premix was added to the broiler ration for 5 days and mortality stopped within a few days. Furthermore the breeder ration of the caged hens, which was basically a corn-soya diet was supplemented with animal protein (herring meal) and biotin $(0.2 \mathrm{mg} / \mathrm{kg}$ diet). During the disease the heaviest birds died; the difference in body weight between the two treatments was lower than in the other progeny tests, therefore it is suspected that mortality has masked the genetical growth capacity of the broilers hatched from the cage hens. The overall difference in body weight of the offspring was somewhat lower than $100 \mathrm{~g}$ at six weeks. Mortality in progeny test 2 and 3 was slightly but not significantly higher for the Al broilers, while food conversion was not affected.

Discussion. - The results obtained during the first period with insemination of diluted (3-fold), stored ( $3 \mathrm{~h}$ ) semen are lower than those obtained previously (Van Wambeke, 1978 ; Van Wambeke ef al., 1979). With the birds used in the present experiment a high hatchability of eggs set ( 90 p. 100 or higher) was only obtained with diluted (3-fold) unstored semen ( $200 \times 10^{6} \mathrm{sp}$.) and diluted (2-fold), stored ( $24 \mathrm{~h}, 400 \times 10^{6} \mathrm{sp}$.) semen (Van Wambeke, 1980). On the other hand, hatchability of eggs set resulting from natural mating was higher than given in the Hubbard management guide 1979- 
1980. According to this data expected hatchability from eggs produced at 34 weeks is 87 p. 100 while 89.8 p. 100 was obtained here.

The serious decline in fertility in NM hens at 54 weeks is not surprising. Although the breeders value of hatchability from eggs set is still 83 p. 100 a sharp decline is often encountered during the second part of the reproductive period with natural mating. This is, like in the present experiment, mainly due to a decrease in fertility while hatchability of fertile eggs is only slightly affected. A possible explanation is the inability of the males to mate due to physical handicaps such as too high body weight and leg problems.

Despite the differences at various ages, reproductive performances over the total period were comparable for both treatments. Future research is needed to obtain more exact information on the reproductive performances of different strains of broiler breeders during the period between 30 and 60 weeks using both NM and Al. It was not possible to test fertility at 60 weeks in this experiment because the hens on deep litter suffered from egg-drop syndrome. Hatchability results obtained here with Al are lower than expected, especially with the high number of spermatozoa inseminated.

The results of the present study are somewhat in contrast with those of Hughes (1978) who found, at least in one trial, lower fertility and hatchability of total eggs with Al compared to NM where the birds were housed on a slat litfer floor. However, the differences in experimental protocol between our experiment and that of Hughes are substantial. An interesting note from Hughes' experiment is that no higher fertility was obtained by increasing the dose of insemination from 0.05 to $0.09 \mathrm{ml}$ (number of spermatozoa not stated).

Differences in body weight of the offspring are higher than in a foregoing experiment (Van Wambeke et al., 1979) where heavy males selected at 3 weeks were compared with all males using Al. Selection of breeder males at 5 weeks after a moderate restriction from 3 weeks is probably more effective.

When broiler breeders are kept on the floor under conditions of natural mating, it is common practice to deliver 15 males together with 100 females. The method of selection of males presented here is realistic in terms of the use of artificial insemination with such a male : female ratio.

After selection on body weight (average +0.5 SD) and semen quality, an average of 22 males is required to inseminate 1000 hens. With a semen volume of $0.5 \mathrm{ml}$ per ejaculate $11 \mathrm{ml}$ are obtained. If this is diluted 3-fold, 330 hens can be inseminated with $0.1 \mathrm{ml}$ diluted semen. Three ejaculates per week are then sufficient for 1000 hens.

Workshop on "Avian male reproduction 》 Nouzilly, Fronce, June 1980.

Résumé. Des coqs reproducteurs lourds ont été sélectionnés à 5 semaines d'âge d'après leur poids corporel. Ont été retenus ceux pesant un poids compris entre la moyenne du lot $+0,5$ écart-type. Les performances de croissance et de reproduction de leur descendance, obtenue par insémination artificielle avec du sperme conservé in vitro, ont été comparées avec celles de coqs non-sélectionnés, utilisés en accouplement naturel au sol.

Les résultats d'incubation des œufs, effectuée à 31,41 et 51 semaines d'âge, font apparaître une meilleure éclosivité des œufs à 31 semaines $(P<0,01)$ pour les coqs utilisés en reproduction naturelle. C'est le contraire, après 50 semaines d'âge à cause d'un déclin de la 
fertilité de ces coqs. Aux différents âges étudiés, la descendance des coqs sélectionnés pour le Doids corporel avait une meilleure croissance $P<0,01$ corporelle.

\section{References}

HUGHES B. L., 1978. Efficiency of producing hatching eggs via artificial insemination and natural mating or broiler breeder pullets. Poultry Sci., 53, 534-537.

MC DANIEL G. R., ROWLAND D. A., COLEMAN M. A., 1979. The effect of egg shell quality on hatchability and embryonic mortality. Poultry Sci., 58, 10-13.

SCHOORL. P., BOERSMA H. Y., 1962. Research on the quality of the egg shell. A new method of determination. Proc. 12th World's Poultry Congr., Sidney, 432-435.

SNEDECOR G. W., COCHRAN W. G., 1967. Statistical methods. lowa, lowa State Univ. Press.

VAN DER SCHAAF A., 1952. Vifalkleuring van stierensperma met een oplossing van anilineblauw en eosine. Tijdschr. Diergeneesk., 77, 815-818.

VAN WAMBEKE F., 1972. Fertility and hatchability results with fowl spermatozoa in fresh and freezedried diluent. Br. Poultry Sci., 13, 179-183.

VAN WAMBEKE F., 1976. The effect of two different methods of semen collection on fertility and hatchability results obtained with stored fowl semen. 5th Eur. Poultry Conf., Malta, 1230-1240.

VAN WAMBEKE F., 1978. The effect of storage time, dilution rate and number of spermatozod on fertility and hatchability obtained with broiler breeders. 16 th World's Poultry Congr., Rio de Janeiro, 148-156.

VAN WAMBEKE F., 1980. The effect of different treatments of fowl semen on duration of fertility and time interval between insemination. 6th Eur. Poultry Conf., Hamburg, IV, 263-270.

VAN WAMBEKE F., MOERMANS R., DE GROOTE G., 1979. Early body weight selection of broiler breeder males in relation to reproductive and growth performance of their offspring. $\mathrm{Br}$. Poultry Sci., 20, 565-570. 